\title{
Spatial Distribution and Temporal Variability of Arsenic in Irrigated Rice Fields in Bangladesh: 1. Irrigation Water
}

\author{
LINDA C. ROBERTS, STEPHAN J. HUG, JESSICA DITTMAR, ANDREAS VOEGELIN, \\ GANESH C. SAHA, M. ASHRAF ALI, A. BORHAN M. BADRUZZAMAN, RUBEN \\ KRETZSCHMAR
}

\section{Supporting Information}

(8 pages, 5 figures, 1 table)

1. Details regarding analytical procedures ..................................................... 2

2. Details well water composition ..................................................................... S4

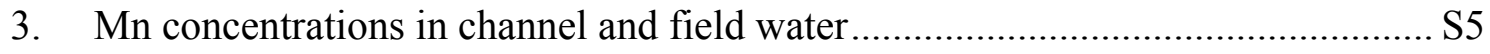

4. TOC concentrations in field water................................................................ S6

5. As concentrations shortly after several irrigation events on fields I and R........... S6

6. Lateral As distribution and As speciation after irrigation of field I from two different

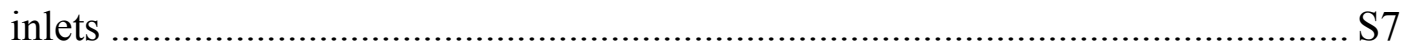

7. Dissolved $\mathrm{As}^{\mathrm{V}}$ concentrations in field water over time .................................... S8 


\section{Details regarding analytical procedures}

Chemicals. All chemicals $\left(\mathrm{NaAsO}_{2}, \mathrm{Na}_{2} \mathrm{HAsO}_{4} \cdot 7 \mathrm{H}_{2} \mathrm{O}, \mathrm{NaBH}_{4}, \mathrm{NaOH}, \mathrm{HCl}\right.$, KI, ascorbic acid, and disodium citrate $\left(\mathrm{Na}_{2} \mathrm{C}_{6} \mathrm{H}_{6} \mathrm{O}_{7} \cdot 1.5 \mathrm{H}_{2} \mathrm{O}\right)$ were analytical grade from Fluka or Merck and used as received. Standards and reagents were prepared with high purity $18 \mathrm{M} \Omega \mathrm{cm}$ water (Millipore).

Arsenic speciation cartridges. Commercially available cartridges containing aluminosilicates and designed to filter $50 \mathrm{~mL}$ (19) were modified to suit the smaller sample volumes (1$2 \mathrm{ml}$ ) required (the stationary phase of each cartridge was used for three smaller cartridges). Cartridge filtration velocity was approximately $1.5 \mathrm{~mL} \mathrm{~s}^{-1} ; 1 \mathrm{~mL}$ effluent was collected after discarding the first $\mathrm{mL}$. Trials carried out with synthetic groundwater $\left(8.2 \mathrm{mM} \mathrm{HCO}_{3}^{-}, 2.5 \mathrm{mM}\right.$ $\mathrm{Ca}, 1.6 \mathrm{mM} \mathrm{Mg}, 3 \mathrm{mg} \mathrm{L}^{-1} \mathrm{P}, 20 \mathrm{mg} \mathrm{L}^{-1} \mathrm{Si}, 250 \mu \mathrm{g} \mathrm{L}^{-1} \mathrm{As}^{\mathrm{III}}$, and $250 \mu \mathrm{g} \mathrm{L}^{-1} \mathrm{As}^{\mathrm{V}}$ ) in the lab showed an average $\mathrm{As}^{\mathrm{III}}$ recovery of $96 \pm 1 \%$ at $\mathrm{pH} 7$, while leakage of $\mathrm{As}^{\mathrm{V}}$ was below $2 \%$ $(\mathrm{n}=3)$. At $\mathrm{pH} 8$ and $8.5, \mathrm{As}^{\mathrm{III}}$ recovery was significantly lower $(82 \pm 2 \%)$, while $\mathrm{As}^{\mathrm{V}}$ leakage remained below $3 \%$ and $4 \%$ respectively ( $\mathrm{n}=3$ at both $\mathrm{pH}$ values). Thus, filtered $\mathrm{As}^{\mathrm{III}}$ concentrations of field water samples may have been underestimated by $20 \%$ or more $(\mathrm{pH}$ values ranged between 7.2 and 8.6 shortly after irrigation; on subsequent days, when As concentrations were very low, max. $\mathrm{pH}$ values of 9.4 were measured).

Sample treatment. All sample vials were well shaken and placed in an ultrasound bath or vortexed for one minute before any sample aliquot was extracted. All measurements were carried out at least twice.

HG-AFS measurements. Since $\mathrm{As}^{\mathrm{III}}$ and $\mathrm{As}^{\mathrm{V}}$ were separated in the field, all samples were analyzed for total arsenic with a hydride generation atomic fluorescence spectrometer (HGAFS; PS Analytical Ltd, U.K.). Measurements were carried out using a $0.5 \mathrm{M}$ disodium citrate buffer ( $\mathrm{pH} 5.0$ ) and $0.7 \% \mathrm{NaBH}_{4}$. To reduce all $\mathrm{As}$ to $\mathrm{As}^{\mathrm{III}}$ prior to analysis, sample aliquots of $200 \mu \mathrm{L}$ were left to react with $100 \mu \mathrm{L} 10 \mathrm{M} \mathrm{HCl}$ and $40 \mu \mathrm{L}$ reducing agent (3 M KI and $0.6 \mathrm{M}$ ascorbic acid) for 30 minutes in the dark before dilution with citrate buffer. The relative 
standard deviation (RSD) of As-measurements was $<5 \%$ for samples with As(tot) concentrations in the range of 50-400 $\mu \mathrm{g} \mathrm{L}^{-1}$.

ICP-OES measurements. $\mathrm{Fe}, \mathrm{Mn}, \mathrm{P}, \mathrm{Si}, \mathrm{Ca}, \mathrm{Mg}, \mathrm{Na}, \mathrm{K}$ and $\mathrm{S}$ were determined by inductively coupled plasma optical emission spectroscopy (ICP-OES; Spectro Ciros CCD) after 1:20 dilution in $1 \% \mathrm{HNO}_{3}$ suprapure (Merck). ICP-OES measurements had $\mathrm{RSD}<5 \%$ for Ca, $\mathrm{Mg}, \mathrm{Fe}, \mathrm{Mn}, \mathrm{Na}, \mathrm{Si}$, and $<10 \%$ for $\mathrm{P}, \mathrm{S}$, and $\mathrm{K}$.

TOC/DOC, $\mathrm{Cl}^{-}$and alkalinity measurements. For the determination of total and dissolved organic carbon (TOC/DOC), unfiltered samples were taken in preacidified (200 $\mu \mathrm{L}$ of $5 \mathrm{M} \mathrm{HCl})$ $30 \mathrm{~mL}$ glass vials. For $\mathrm{Cl}^{-}$determination, samples were collected into $4 \mathrm{~mL}$ polypropylene vials preacidified with $80 \mu 12 \mathrm{M} \mathrm{HNO}_{3}$; for alkalinity measurements, unfiltered, unacidified samples were collected. All samples for TOC/DOC and alkalinity measurements were cooled to $4^{\circ} \mathrm{C}$ as soon as possible. $\mathrm{Cl}^{-}$and alkalinity were determined in irrigation well samples only. TOC- and DOC-measurements were carried out with a high performance TOC/TN analyser (high TOC II, Elementar Analysensysteme, Germany), $\mathrm{Cl}^{-}$was determined by ion chromatography (761 Compact IC, Metrohm AG, Switzerland) and alkalinity was measured by titration to $\mathrm{pH} 4.5$ with $0.1 \mathrm{M} \mathrm{HCl}$ after $0.45 \mu \mathrm{m}$-filtration. 


\section{Details well water composition}

Irrigation water was sampled during three field campaigns, spanning 7-10 days each: shortly after the onset of irrigation in January 2005, towards the close of the irrigation season in April 2005, and during the subsequent irrigation season in February 2006. To test whether well water composition varied over time, samples from the irrigation well were taken on different days and at different times of day throughout the campaigns, allowing the well to run for at least 30 minutes prior to sampling. In table S1 means and standard deviations of all measured parameters are reported separately for each sampling campaign.

Table S1. Well Water Composition at the Field Site. Mean Values and Standard Deviations of All Parameters Measured in January 2005, April 2005, and February $2006(n=$ Number of Samples).

\begin{tabular}{|c|c|c|c|c|c|c|}
\hline & \multicolumn{2}{|c|}{ January 2005} & \multicolumn{2}{|c|}{ April 2005} & \multicolumn{2}{|c|}{ February 2006} \\
\hline & total $(n=8)$ & diss. $(n=9)$ & total $(n=9)$ & diss. $(n=8)$ & total $(n=10)$ & diss. $(n=10)$ \\
\hline $\operatorname{As}\left(\mu \mathrm{g} \mathrm{L}^{-1}\right)$ & $397 \pm 3$ & $396 \pm 5$ & $398 \pm 4$ & $397 \pm 3$ & $396 \pm 11$ & $398 \pm 9$ \\
\hline$A s^{\text {IIII }}\left(\mu \mathrm{g} \mathrm{L}^{-1}\right)$ & / & $299 \pm 29 *$ & / & $315 \pm 9$ & / & $355 \pm 12$ \\
\hline $\mathrm{Fe}\left(\mathrm{mg} \mathrm{L}^{-1}\right)$ & $11.0 \pm 0.1$ & $10.9 \pm 0.2$ & $10.9 \pm 0.1$ & $10.6 \pm 0.2$ & $11.0 \pm 0.1$ & $11.0 \pm 0.1$ \\
\hline $\operatorname{Mn}\left(\mu \mathrm{g} \mathrm{L}^{-1}\right)$ & $688 \pm 3$ & $685 \pm 2$ & $694 \pm 4$ & $687 \pm 4$ & $667 \pm 3$ & $667 \pm 4$ \\
\hline $\mathrm{P}\left(\mathrm{mg} \mathrm{L}^{-1}\right)$ & $1.97 \pm 0.06$ & $1.97 \pm 0.06$ & $1.97 \pm 0.04$ & $1.88 \pm 0.08$ & $1.96 \pm 0.08$ & $1.92 \pm 0.06$ \\
\hline $\mathrm{Si}\left(\mathrm{mg} \mathrm{L}^{-1}\right)$ & $20.0 \pm 0.1$ & $19.9 \pm 0.1$ & $20.1 \pm 0.1$ & $20.0 \pm 0.2$ & $20.3 \pm 0.1$ & $20.4 \pm 0.1$ \\
\hline $\mathrm{Ca}\left(\mathrm{mg} \mathrm{L}^{-1}\right)$ & $99.2 \pm 0.5$ & $98.6 \pm 0.2$ & $98.5 \pm 0.7$ & $98.1 \pm 0.3$ & $99.8 \pm 0.7$ & $99.9 \pm 0.4$ \\
\hline $\operatorname{Mg}\left(\mathrm{mg} \mathrm{L}^{-1}\right)$ & $26.5 \pm 0.1$ & $26.5 \pm 0.1$ & $26.7 \pm 0.2$ & $26.6 \pm 0.1$ & $26.8 \pm 0.2$ & $26.8 \pm 0.1$ \\
\hline $\mathrm{S}\left(\mathrm{mg} \mathrm{L}^{-1}\right)$ & $<1$ & $<1$ & $<1$ & $<1$ & $<1$ & $<1$ \\
\hline $\mathrm{Cl}\left(\mathrm{mg} \mathrm{L}^{-1}\right)$ & I & 1 & I & $8.2(n=1)$ & / & $9.9(n=2)$ \\
\hline TOC $\left(\mathrm{mg} \mathrm{L}^{-1}\right)$ & \multicolumn{2}{|c|}{$7.7 \pm 0.2(n=4)$} & \multicolumn{2}{|c|}{1} & \multicolumn{2}{|c|}{1} \\
\hline alkalinity $(\mathrm{mM})$ & \multicolumn{2}{|c|}{$\frac{1}{60+01(n=3)}$} & \multirow{2}{*}{\multicolumn{2}{|c|}{$8.63(n=1)$}} & \multirow{2}{*}{\multicolumn{2}{|c|}{$8.36(n=1)$}} \\
\hline & \multirow{2}{*}{\multicolumn{2}{|c|}{$<1(n=3)$}} & & & & \\
\hline $\mathrm{O}_{2}\left(\mathrm{mg} \mathrm{L}^{-1}\right)$ & & & \multicolumn{2}{|c|}{1} & \multicolumn{2}{|c|}{$<1(n=2)$} \\
\hline $\begin{array}{l}\text { conductivity } \\
(\mathrm{uS} \mathrm{cm}-1)\end{array}$ & \multicolumn{2}{|c|}{ / } & \multicolumn{2}{|c|}{$780(n=2)$} & \multicolumn{2}{|c|}{$789 \pm 12(n=2)$} \\
\hline $\mathrm{T}\left({ }^{\circ} \mathrm{C}\right)$ & \multicolumn{2}{|c|}{$25.9 \pm 0.3(n=7)$} & \multicolumn{2}{|c|}{$26.7 \pm 0.3(n=3)$} & \multicolumn{2}{|c|}{$26.2 \pm 0.1(n=10)$} \\
\hline
\end{tabular}


In February 2006, a higher $\mathrm{As}^{\mathrm{III}} / \mathrm{As}^{\mathrm{V}}$ ratio was measured than during the two previous sampling campaigns. However, since the other parameters appear stable this is unlikely to reflect a real shift in As speciation. As ${ }^{\mathrm{III}}$ determination, involving filtration through a speciation cartridge in the field, was less reproducible than determination of total arsenic, as is apparent from the larger standard deviations. Also, the $\mathrm{As}^{\mathrm{III}}$ value determined in January must be considered in light of the fact that only 3 speciated samples were taken.

\section{Mn concentrations in channel and field water}
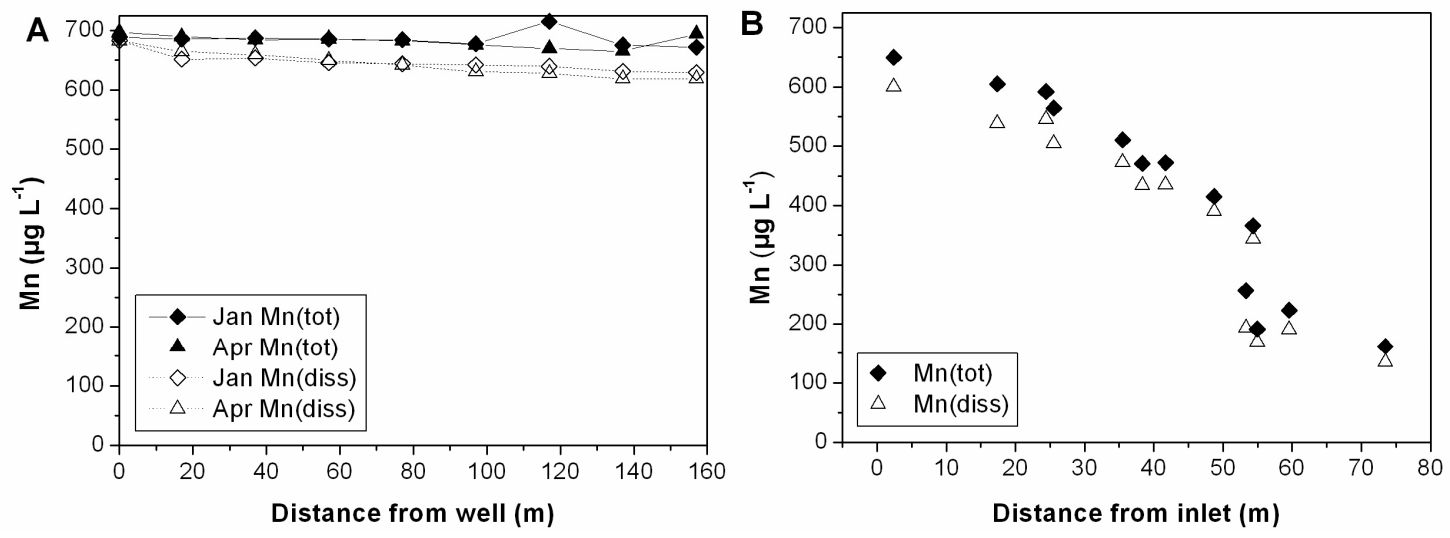

Figure S1. Total and dissolved $\left(0.2 \mu \mathrm{m}\right.$-filtered) Mn concentrations $\left(\mu \mathrm{g} \mathrm{L^{-1 }}\right)$. (A) In channel water sampled in January and April 2005. (B) In irrigation water on field I shortly (0-2.0 h) after a 2.75-h irrigation period in February 2006. 


\section{TOC concentrations in field water}
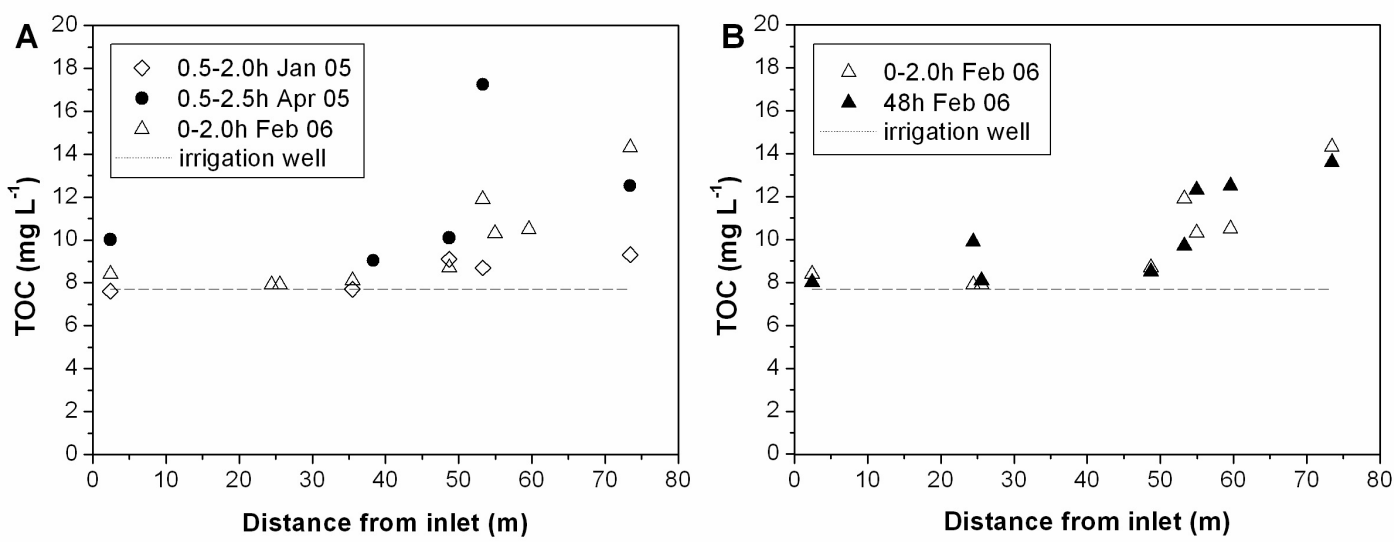

Figure S2. TOC $\left(\mathrm{mg} \mathrm{L}^{-1}\right)$ in irrigation water on field I. (A) shortly after irrigation in January 2005, April 2005 and February 2006. (B) At different time intervals after irrigation in February 2006. The TOC concentration of the well water is shown for comparison.

\section{As concentrations shortly after several irrigation events on fields I} and $\mathbf{R}$

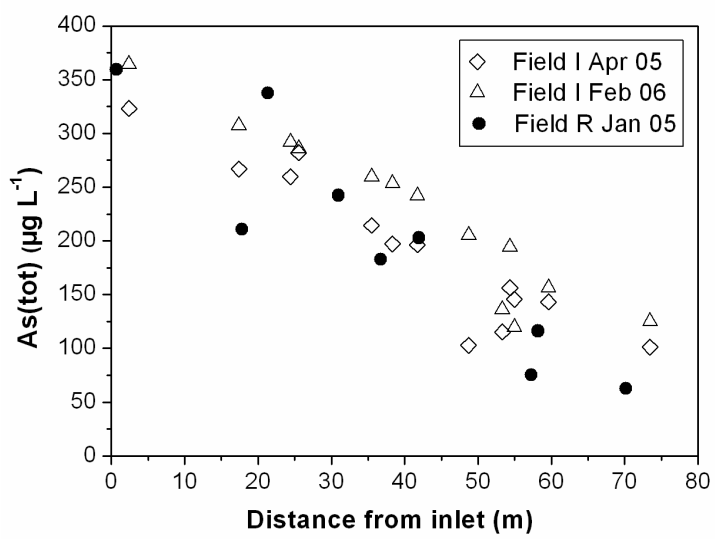

Figure S3. As(tot) concentrations $\left(\mu \mathrm{g} \mathrm{L}^{-1}\right)$ in field water shortly after different irrigation events on field I (Apr 2005 (0.5-2.5 h) and Feb 2006 (0-2.0 h)) and field R (Jan 2005 (0-2.0 h)) plotted as a function of distance from the respective inlets. 


\section{Lateral As distribution and As speciation after irrigation of field I from two different inlets}

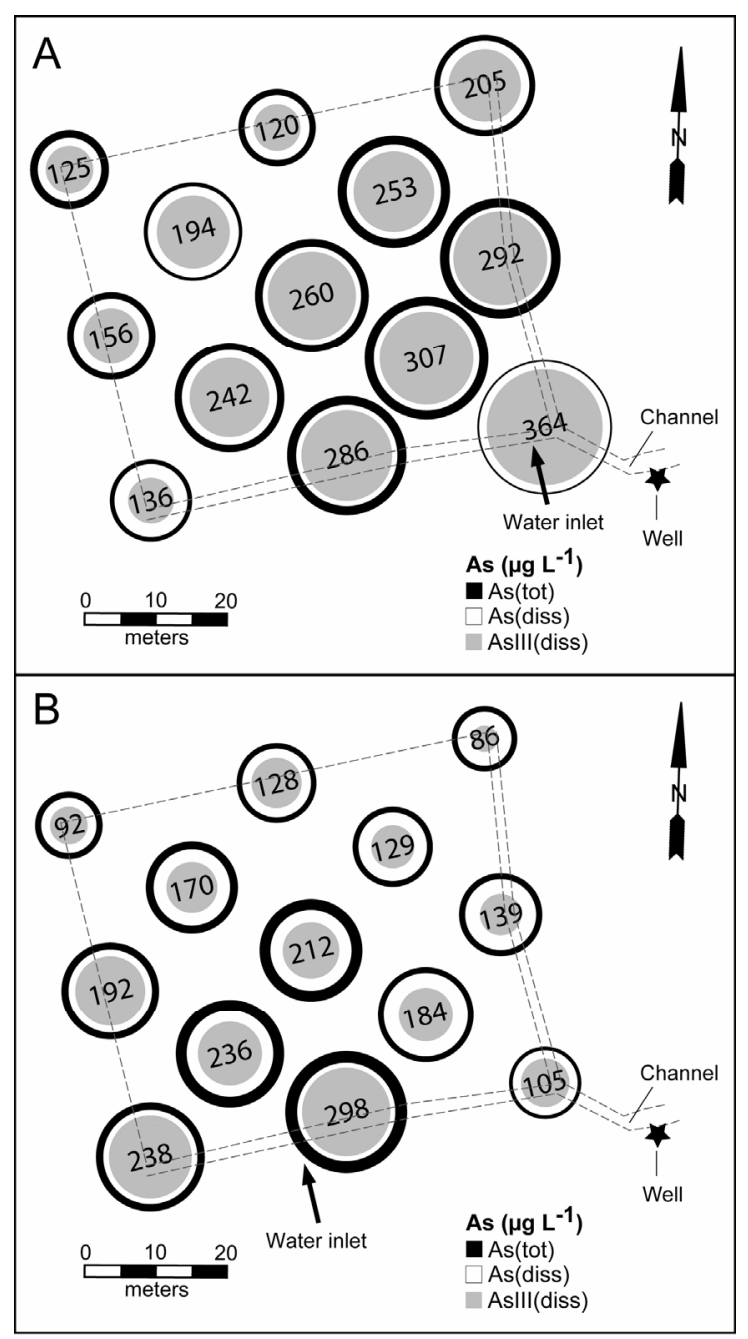

Figure S4. Horizontal distribution of As species $\left(\mu \mathrm{g} \mathrm{L}{ }^{-1}\right)$ in field water on field I, shortly after irrigation from the regular inlet (A) and from a temporarily shifted inlet (B) in February 2006. Concentrations of As(tot), As(diss), and $\mathrm{As}^{\mathrm{III}}$ (diss) are represented by the areas of the outer black, middle white, and inner grey circles respectively. As(tot) concentrations are also shown in numbers. (A) 0-2.0 h after a 2.75-h irrigation period. (B) 1.0-3.0 h after a 2.5 -h irrigation period. The effect of the inlet position on horizontal As distribution is clearly visible. In addition, the effect of longer time elapsed in (B) between the close of irrigation and the beginning of sampling on $\mathrm{As}^{\mathrm{III}}$ oxidation, colloid formation and colloidal settling is noticeable. 


\section{Dissolved $\mathrm{As}^{\mathrm{V}}$ concentrations in field water over time}

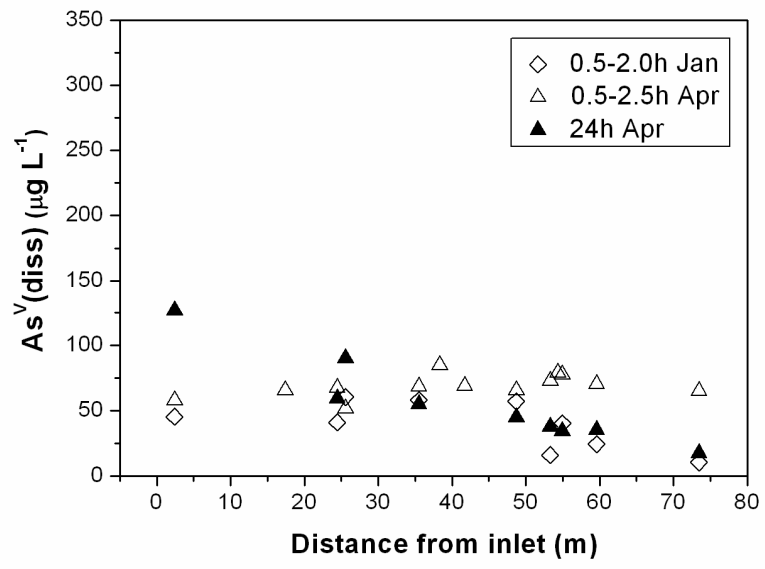

Figure S5. Dissolved $\mathrm{As}^{\mathrm{V}}(\mu \mathrm{g} \mathrm{L}-1)$ in irrigation water on field I at different time periods after irrigation in January and April 2005. 